\title{
DEPRESSED RNA SYNTHESIS IN THE BRAINS AND LIVERS OF THYROIDECTOMIZED, NORMAL AND HORMONE INJECTED RATS
}

\author{
HERBERT H KOHL \\ Mental Health Research Institute, University of Michigan Medical Center, Ann Aibor, Mich 48104 \\ ( $U S A)$
}

(Accepted November 15th, 1971)

\section{INTRODUCTION}

Neonatally thyroidectomized rats incorporate in vivo injected amino acids into brain protein at lower rates than do normal control anımals, 2,12 Activities of a number of brain enzymes are also reduced in such hypothyroid rats ${ }^{10,11,17,23}$ Early administration of thyroxine is often effective in restoring brain enzyme activity and protein synthesis to normal levels ${ }^{12,17,23}$ Excellent reviews of the above aspects have appeared $6,14,23$

Two studies have recently appeared comparıng brain RNA synthesis in hypothyroid and normal rats judged by rates of incorporation of in vivo injected orotic acıd, a pyrımıdıne precursor, into brain RNA In one, Balázs et al ${ }^{3}$ found no differences in the normal and hypothyroid anımals, but did report a $10 \%$ reduction in rate of liver RNA synthesis in the latter, suggesting for brain, an effect of thyroid hormones on protein synthesis rather than at the transcriptional level Geel and Timiras ${ }^{13}$ reported partıal agreement with Balázs, but in contrast demonstrated an increased turnover of pyrimidine nucleotides in the cortices of hypothyroid rats

It seems unlikely to us that the effects of thyroid hormones are confined to brain cortex translational processes, since cortices of hypothyroid rats have lower RNA/ DNA ratios than normal control anımals ${ }^{3,13,23}$ Moreover, recent reports ${ }^{10,25}$ suggest a probable effect at the transcriptional level in 10-day-old hypothyroid rat brain A depressed RNA synthesis was also shown in rat brain stem following hypophysectomy ${ }^{15}$ Thus neural tissue can respond to some hormonal alterations, by changed rates of RNA synthesis, in qualitatively the same fashıon as peripheral organs such as liver ${ }^{29}$ It is known that neonatal thyroidectomy results in altered brain vascular patterns $^{9}$ The entry of amino acids into brain tissue is also significantly changed 10,28 as is the turnover of RNA ${ }^{13}$ in the hypothyrold rat brain The use of in vivo injected precursor substances to determine synthetic capacity, in response to hormonal alteration, when subject to such complications may assess the sum of all processes rather than specifically estimate synthetic capacity Such difficulties have been encountered by others and discussed ${ }^{1,4,18}$ The present study compares RNA and nuclear protein 
synthetic capacity in normal and thyroidectomized rats using $i n$ itro techniques which allow control of the specific activity of the immediate precursor substances at the reaction site and assure saturation of the enzymatic apparatus with substrate The results obtained here do show depressed brain RNA synthesis and a larger depression of liver RNA synthesis than seen by others ${ }^{3}$ using in wivo injection of orotic acid

MATERIALS AND METHODS

\section{Chemicals}

ATP, CTP, GTP, UTP, yeast RNA, salmon sperm DNA, 2-phosphoenol pyruvic acid, pyruvate kinase (rabbit muscle), ribonuclease $5 \times$ cryst (bovine pancreas), spermidıne trıhydrochloride, sucrose, and Tris-(hydroxymethyl)-amınomethane (all A grade) were obtained from the Calıfornıa Bıochemical Corp (Los Angeles, Calıf) $\mathrm{KCl}$ and $\mathrm{MgCl}_{2}$ from the Sigma Chemical Company Deoxyribonuclease I (bovine pancreas) electrophoretically pure was from the Worthington Biochemical Corpordtion (Freehold, N J ) ${ }^{3} \mathrm{H}$-GTP (spec act $100 \mathrm{mCl} / \mathrm{mmole}$ ) was purchased from the Schwartz/Mann Biochem Co [4,5-3 H]leucine (spec act of $5 \mathrm{Cl}_{1} / \mathrm{mmole}^{-}$) was purchased from New England Nuclear Corp (Boston, Mass) Sodıum L-thyroxine was supplied by the Smith, Kline and French Laboratories

\section{Experimental hypothyroidısm}

Long-Evans rats born to mothers maintaıned on a low lodıne diet $(017 \mu \mathrm{g}$ $I_{2} / g$ diet) were radiothyroidectomized one day after birth by injection of $100 \mu \mathrm{Cl}_{1}$ of carrier-free ${ }^{131}$ I in accordance with the procedure of Goldberg and Cha1koff ${ }^{16}$

\section{Replacement therapy}

Commencing on the 6th day after birth, groups of hypothyroid rats received daily replacement therapy of either sodium L-thyroxine ( $10 \mu \mathrm{g} / 100 \mathrm{~g}$ body weight) or of bovine growth hormone ${ }^{24}(100 \mu \mathrm{g}$ per rat) Other hypothyrold and normal control groups were injected intraperitoneally with a similar volume of the alkalıne vehicle used to dissolve the hormones

\section{Symbols used for various animal groups}

Normal - intact offspring of pregnant mothers fed a low lodine diet

$\overline{\mathrm{T}}$ (thyroidectomized) - offspring of mothers on low iodine diet injected with $100 \mu \mathrm{C} 1$ of $131 \mathrm{I} /$ rat at one day of age

$\overline{\mathbf{T}}+\mathrm{T}_{4}$ (thyroidectomized, thyroxine injected) - animals of the thyroidectomized group injected intraperitoneally with $10 \mu \mathrm{g}$ of sodium L-thyroxine/ $100 \mathrm{~g}$ body weight dally from 6th day of age

$\overline{\mathrm{T}}+\mathrm{GH}$ (thyroidectomized, growth hormone injected) -- animals of the 
thyroidectomized group injected intraperitoneally with growth hormone $100 \mu \mathrm{g} / \mathrm{rat}$ daily from 6 th day of age

\section{Isolation of brain and liver nuclet}

Rats were sacrificed by decapitation, brains and livers were removed and dissected free of the larger blood vessels and connective tissue Brain cortices and diencephalons were pooled, minced and then homogenized manually in a Dounce homogenizer (pestle A) Livers were minced and thereafter homogenized in an electrically driven homogenızer Ice-cold $025 M$ sucrose containıng $005 M$ Tris buffer $\mathrm{pH} 69$, $0025 M \mathrm{KCl}$ and $0005 M \mathrm{MgCl}_{2}$ (referred to as TKM) was used for homogenization $1 / 5(\mathrm{w} / \mathrm{v})$ A crude nuclear fraction was isolated by centrifugation $(2000 \times g$ for 15 min) through a two layer discontinuous sucrose gradient of $025 \mathrm{M}$ and $040 \mathrm{M}$ sucrose containing TKM The supernate containing mitochondria, microsomes and polysomes was discarded The crude nuclear pellet was resuspended in $025 \mathrm{M}$ sucrose TKM Hypertonic sucrose $23 M$ (TKM) was added to a final sucrose concentration of $165 \mathrm{M}$ and samples were mixed by repeated inversion Ten ml of $18 \mathrm{M}$ sucrose TKM or $20 M$ sucrose TKM were added as an underlay in brain and liver samples respectively and centrifugation of these two layer discontınuous sucrose gradients at $37,000 \times g$ for 45 min was carried out yıelding a purified nuclear pellet These nuclear pellets were suspended in $025 \mathrm{M}$ sucrose and observed by oll immersion light microscopy subsequent to methyl green staining The nuclei appeared intact and the brain nuclear preparations were similar to those described by Sporn et al ${ }^{27}$ Both neuronal and glial nucleı were evident, exhibitıng the morphological characteristics described by Rappoport et al ${ }^{26}$ Aliquots of these nuclear suspensions in $025 \mathrm{M}$ sucrose were subsequently used to study nuclear RNA and protein synthesis

\section{Determination of nucletc actd concentration}

RNA and DNA were extracted from the nuclear suspensions by procedures described by Munro ${ }^{22}$ RNA concentration was determined from the spectral absorbance at $260 \mathrm{~nm}$ after alkaline hydrolysis and acid reprecipitation Yeast RNA was treated similarly and used as a standard DNA concentration was determined using the diphenylamine reaction as modified by Burton ${ }^{5}$ Salmon sperm DNA was used as a standard

\section{Incubation and determination of radioactivity}

Aliquots of the nuclear suspensions were added to chilled tubes containing incubation medium $\left[{ }^{3} \mathrm{H}\right]$ Leucine or ${ }^{3} \mathrm{H}$-GTP was added and the tubes were incubated at $37^{\circ} \mathrm{C}$ for $10 \mathrm{~min}$ (RNA assay) or 20 min (nuclear protein synthesis) RNA assays were done in triplicate using the complete assay mixture Duplicate tubes containing no exogenously added nucleoside triphosphates other than the one radioactive triphosphate were incubated along with the three samples of the complete mixture Any ra- 
dioactivity observed in the incomplete system was subtracted from that seen in the complete system RNA synthesis was termınated by addıng $5 \mathrm{ml}$ of ice-cold $35 \%$ perchloric acid containing $01 M$ sodium pyrophosphate These acid-precipitated samples were left in an ice bath for $15 \mathrm{~min}$ and then collected on glass fiber filters (GF/C) Assays of nuclear protein synthesis were conducted in a total of 5 tubes containing the specified incubation medium Two tubes were used as blanks, acid being added at zero tıme ( $5 \mathrm{ml}$ of $05 \mathrm{~N}$ perchloric acid containıng $1 \mathrm{mg} / \mathrm{ml}$ of non-radioactive L-leucine) Reactions were terminated by addition of similar acid solutions used for the blank tubes These acid-precipitated samples containing radioactive protein were left in an ice bath for $30 \mathrm{~min}$ and then heated at $90^{\circ} \mathrm{C}$ for $30 \mathrm{~min}$ The heated samples were cooled and collected on glass fiber filters These filters containıng radıoactıve RNA or protein were now washed 5 times with cold $1 \mathrm{M} \mathrm{HCl}$, twice with cold $95 \%$ ethanol and once with ether Radioactivity was counted (after hyamine solubilization) by liquid scintıllation at $37 \%$ efficiency in a toluene system contaınıng PPO (2,5 diphenyloxazole) and dimethyl POPOP (1,4-bis[2-(4-methyl-5-phenyloxazole)]-benzene)

\section{Assay concentrations}

In vitro synthesis of rat brain RNA (after Dutton and Mahler ${ }^{8}$, with slight modification) $\mu$ Moles $/ \mathrm{ml}$ (total volume $10 \mathrm{ml}$ ) Tris buffer $\mathrm{pH} 85(100)$, spermidine $3 \mathrm{HCl}(2)$, phosphoenol pyruvate (2), pyruvic kınase $25 \mathrm{E} \mathrm{U} \mathrm{Mg}{ }^{2+}(8)$, sucrose (100), ATP, CTP, UTP (0 2) and ${ }^{3} \mathrm{H}-\mathrm{GTP}(002), 1 \mu \mathrm{Cl}$

In vitro liver RNA synthesis was determined using an assay system described by McGregor and Mahler ${ }^{20}$

$\mu$ Moles $/ \mathrm{ml}$ (total volume $10 \mathrm{ml}$ ) ATP, UTP, GTP and CTP $(005) 1 \mu \mathrm{C} 1$ of ${ }^{3} \mathrm{H}-\mathrm{GTP}$ Tris (50) pH $85, \mathrm{Mg}^{2+}(15) \mathrm{NaF}(8)$, phosphoenol pyruvate (2 5), pyruvic kınase $25 \mathrm{E} \mathrm{U}$ and spermidine $(56)$

In vitro nuclear protein synthesis brain and liver $\mu \mathrm{Moles} / \mathrm{ml}$ (total volume $10 \mathrm{ml}$ ) L-[ $\left.{ }^{3} \mathrm{H}\right]$ leucine $(0011), 10 \mu \mathrm{C}$, sodium phosphate $\mathrm{pH} 6(100)$, phosphoenol pyruvate (2), pyruvıc kınase $25 \mathrm{E} \mathrm{U}, \mathrm{MgCl}_{2}(2)$, and sucrose (100)

\section{RESULTS}

\section{Body and organ welghts}

Table I presents representative body, liver and brain weights of 45-day-old female rats subjected to hormonal manipulations (see Methods) Body, liver and brain weights were significantly reduced in the thyroidectomized and in the thyroidectomized + growth hormone group $(P<0005)$ relative to the normal or the thyroidectomized + thyroxine group Although the weights of the thyroidectomized group receiving dally growth hormone $(100 \mu \mathrm{g})$ were significantly greater than the thyroidectomized group, they were much below the normal or the thyroxine supplemented animals The minimal effective dose of this growth hormone preparation was reported as $10 \mu \mathrm{g}$ with respect to the Tibia test ${ }^{13}$ There were no significant dif- 


\section{TABLE I}

BODY AND ORGAN WEIGHTS OF HORMONALLY ALTERED AND NORMAL RATS

The thyroidectomized group receiving thyroxin injections and the group of normal controls were not significantly different from one another All other experimental groups were significantly different from one another in terms of body, liver and brain weight $(P<0005)$ based upon comparison by Student's $t$-test Values are means \pm SEM Numbers between parentheses indicate number of anımais

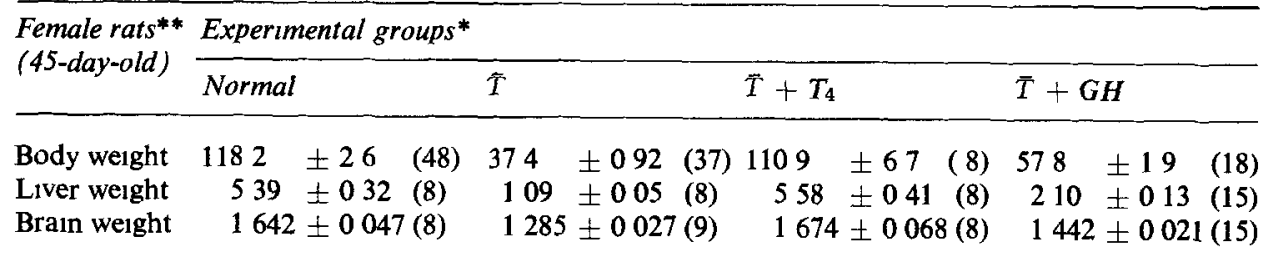

* Experimental groups are as defined in the Methods section

** Weight in grams

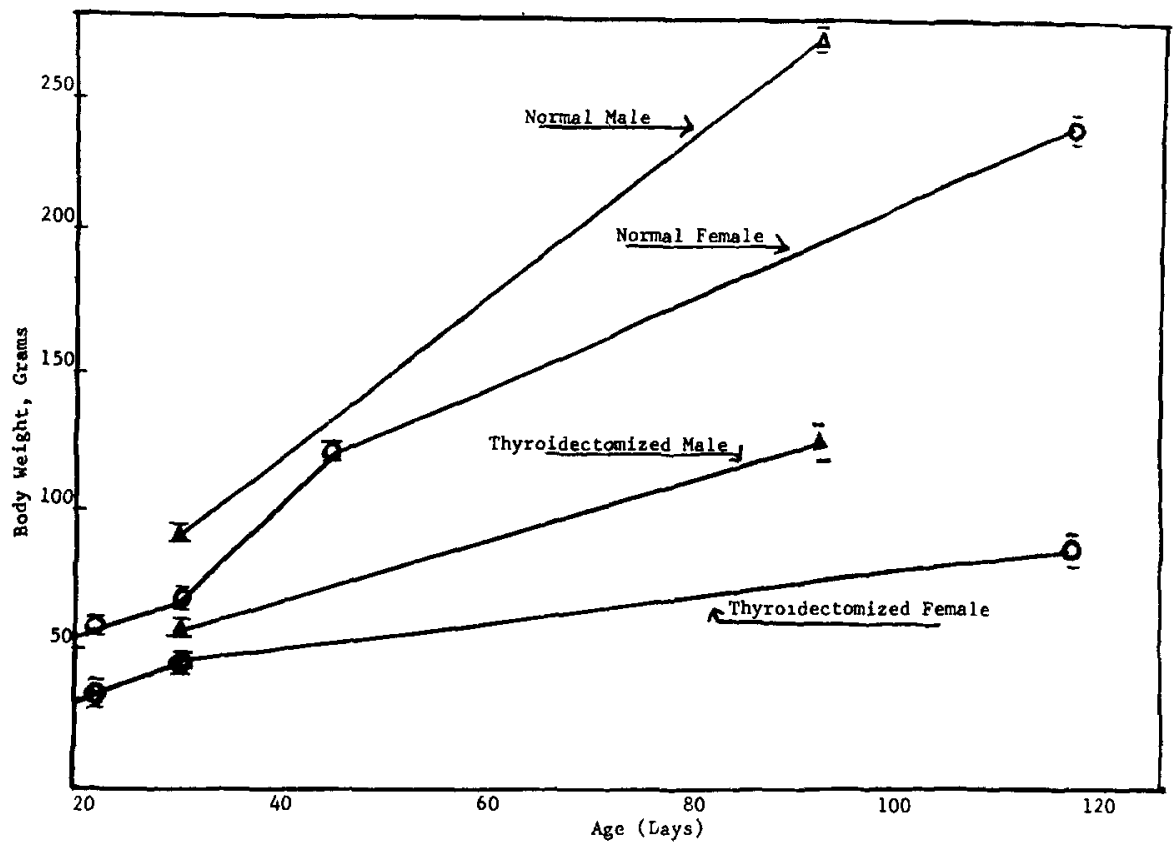

Fig 1 Effect of neonatal thyroidectomy on body weight increase of male and female rats Means \pm S E M are shown for at least 15 animals at each time interval

ferences between normal controls and the thyroidectomized thyroxine supplemented anımals, thus indicating that the effects attributed to thyroxine lack were not due to radiation damage The effects of thyroid deprivation on body weight appeared generally independent of and were of similar magnitude in rats of either sex (Fig 1) Body weight differences between normal and the thyroidectomized groups intensified as the anımals became older Thyroidectomized anımals receiving thyroxine re- 


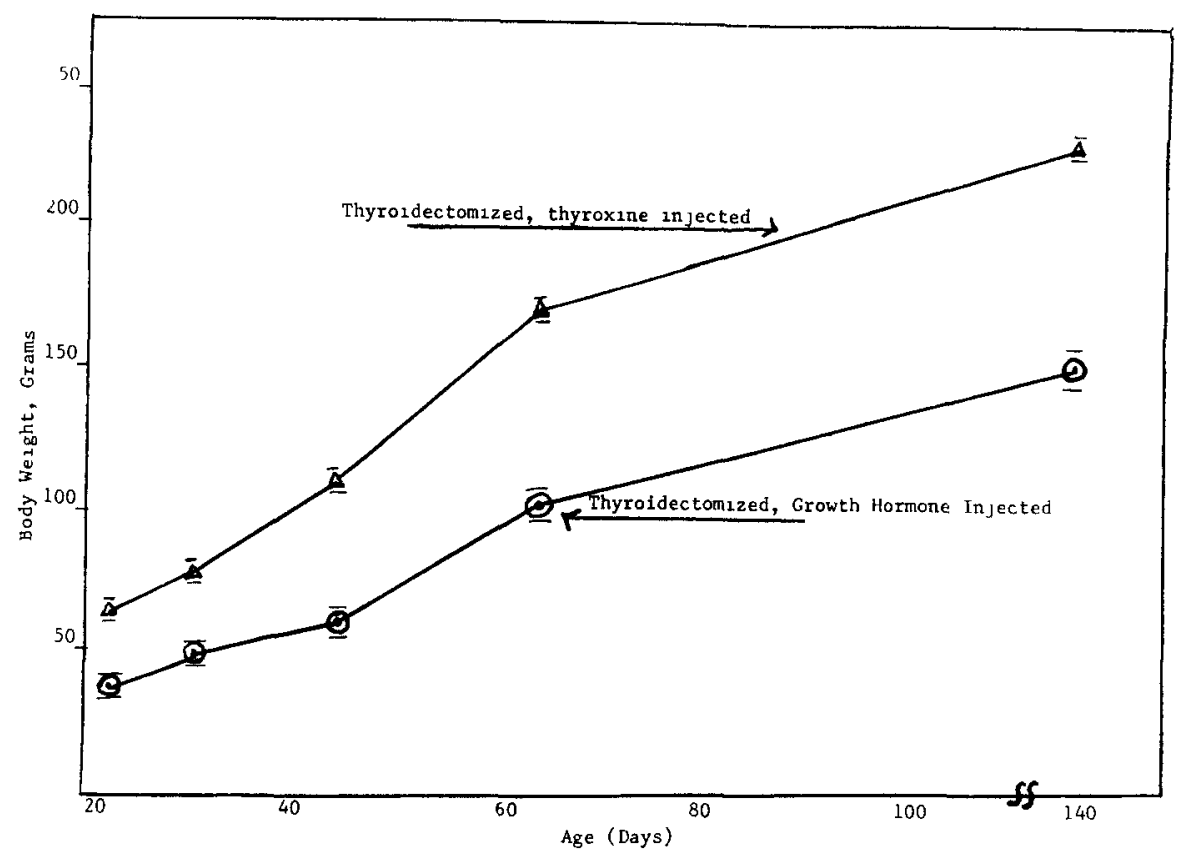

Fig 2 Effect of neonatal thyroidectomy and replacement therapy on body weight increase of female rats Means $\pm S E M$ are shown for at least 10 anımals at each tıme interval

\section{TABLE II}

EFFFCTS OF DIFFERENT COMPONENTS AND INHIBITORS ON INCORPORATION

The complete system contains Tris buffer ( $\mathrm{pH} 85$ ) $100 \mathrm{mM}$, spermidine $2 \mathrm{mM}$, 2-phosphoenol pyruvic acid $2 \mathrm{mM}$, pyruvate kınase $25 \mathrm{E} \mathrm{U}, \mathrm{MgCl}_{2} 8 \mathrm{mM}$, sucrose $100 \mathrm{~m} M$, ATP, CTP, UTP 02 $\mathrm{mM}$, and ${ }^{3} \mathrm{H}-\mathrm{GTP} 05 \mu \mathrm{C}_{1}$ (spec act $100 \mathrm{mCl} / \mathrm{mmole}$ ) Nuclear DNA $100 \mu \mathrm{g}$ all in a total volume of $10 \mathrm{ml}$ Elıminated components were replaced with an equal volume of glass distilled water Values are the means of triplicate determinations of a typical experiment Further details are given in the Methods section

\begin{tabular}{|c|c|c|}
\hline $\begin{array}{l}\text { Incubation mixture } \\
\text { (additions or delettons) }\end{array}$ & $\begin{array}{l}\text { Specific radioactivity } \\
(\text { disint } / \text { min/100 } / \mathrm{g} \text { DNA) }\end{array}$ & $\begin{array}{l}\text { Per cent } \\
\text { of complete } \\
\text { system }\end{array}$ \\
\hline Complete system & 1061 & 100 \\
\hline Mınus ATP, UTP and CTP & 76 & 7 \\
\hline Minus phosphoenol pyruvate and pyruvate kınase & 517 & 49 \\
\hline Minus spermidine & 494 & 47 \\
\hline Minus $\mathrm{Mg}^{2+}$ & 625 & 59 \\
\hline Plus $(8 \mathrm{~m} M) \mathrm{NaF}$ & 1125 & 106 \\
\hline Plus $(8 \mathrm{~m} M) \mathrm{NaF}$ and $(70 \mathrm{~m} M) \mathrm{KCl}$ & 1617 & 152 \\
\hline $\begin{array}{l}\text { Plus ( } 8 \mathrm{~m} M \mathrm{NaF}, 70 \mathrm{mM} \mathrm{KCl}) \text { and } 100 \mu \mathrm{g} \text { salmon } \\
\text { sperm DNA }\end{array}$ & 1618 & 152 \\
\hline Plus $60 \mu \mathrm{g}$ actınomycin $\mathrm{C}$ & 111 & 11 \\
\hline Plus ( $20 \mathrm{mM}$ ) sodium pyrophosphate & 66 & 6 \\
\hline Plus $300 \mu \mathrm{g}$ Pan RNAse* & 50 & 5 \\
\hline Plus $300 \mu \mathrm{g}$ DNAse* & 58 & 5 \\
\hline Complete system* & 1100 & 104 \\
\hline
\end{tabular}

* Ten min preincubation at $37^{\circ} \mathrm{C}$

Brain Research, 40 (1972) 445-458 


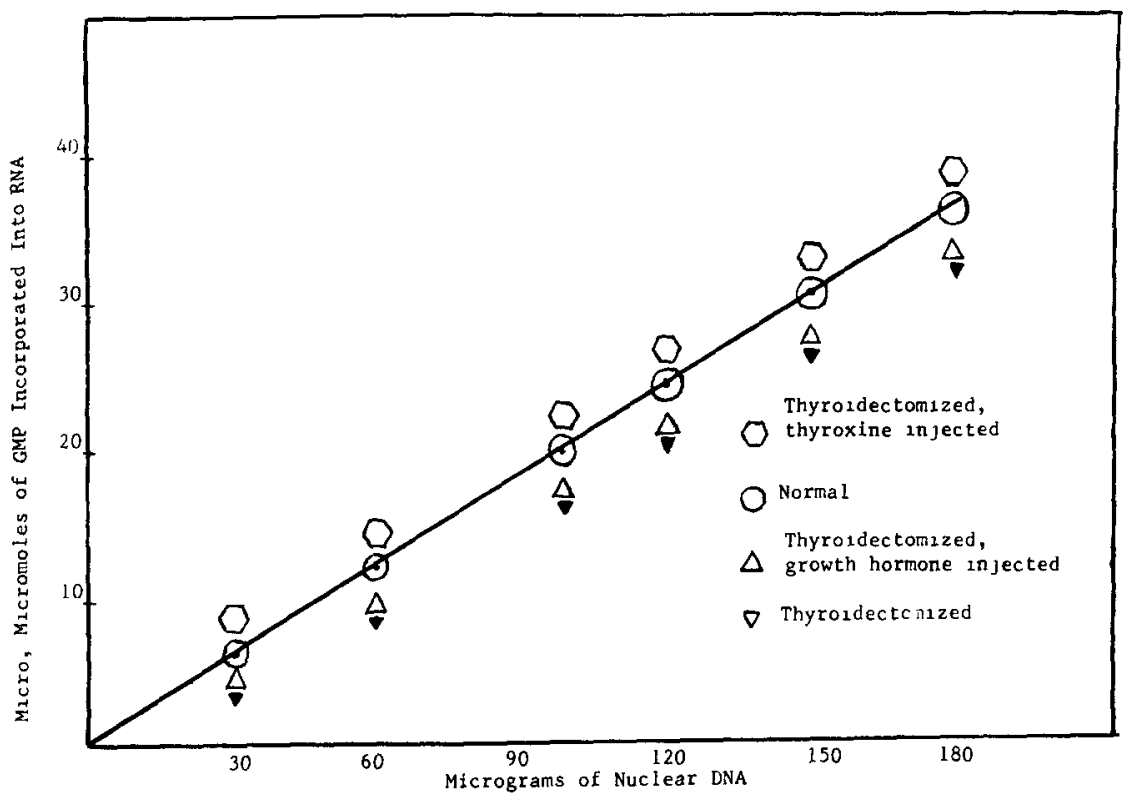

Fig 3 Incorporation dependence upon concentration of brain nuclei of normal and hormonally altered rats Each point represents the mean of single assays in triplicate

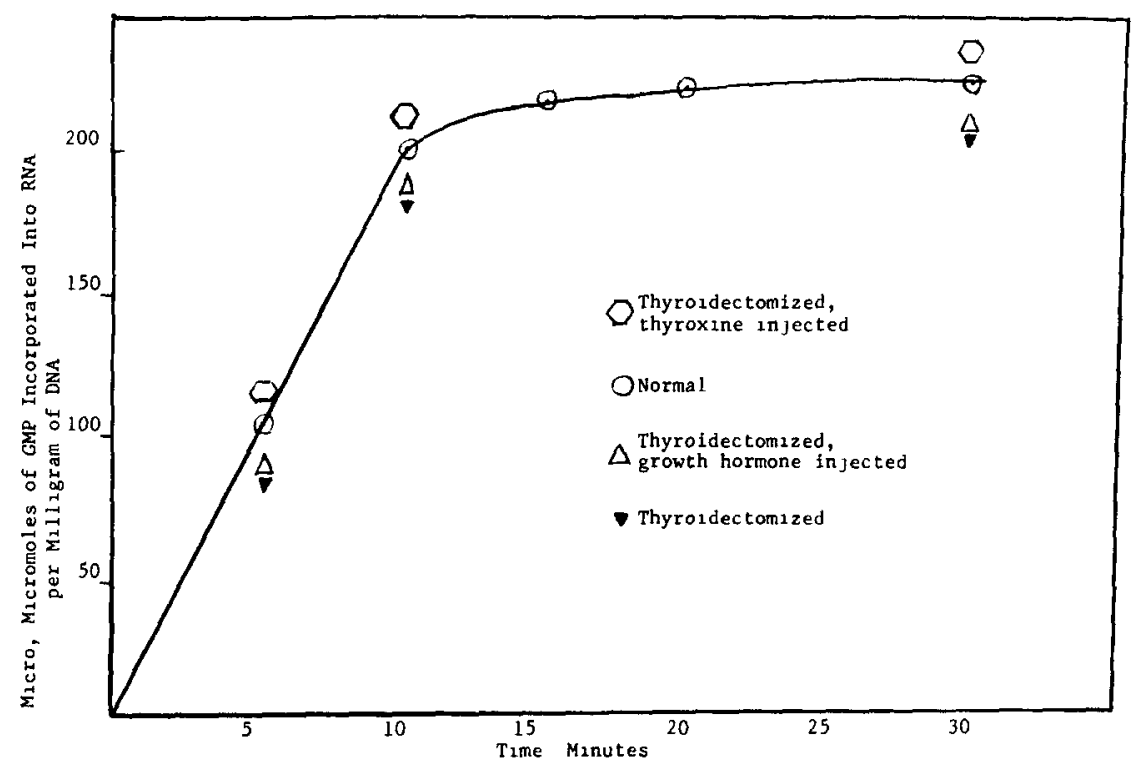

Fig 4 Time dependence of incorporation using brain nuclet from normal or hormonally altered rats Each point shown represents the mean of a single assay in triplicate 


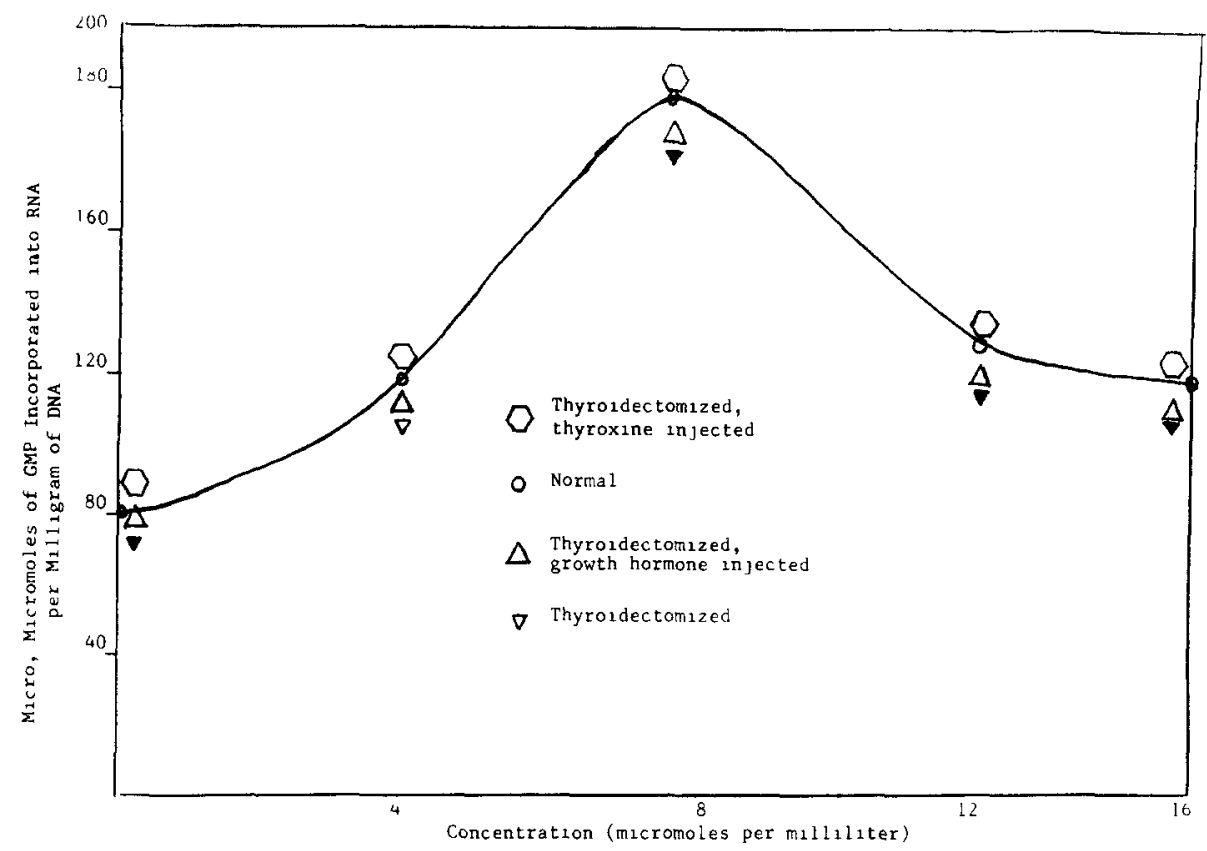

Fig 5 Effect of $\mathrm{Mg}^{2+}$ concentration on in vitro incorporation of ${ }^{3} \mathrm{H}-\mathrm{GMP}$ into RNA Points represent means of single assays in triplicate

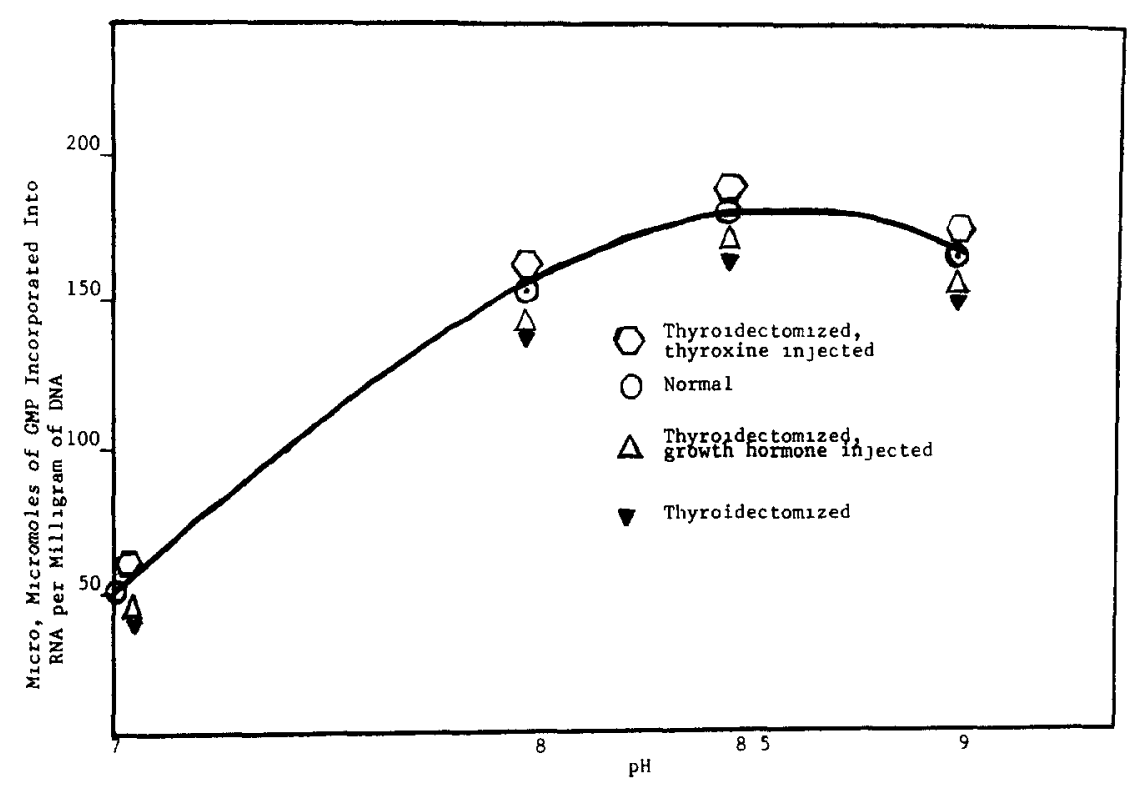

Fig 6 Effect of pH on in vitro incorporation of ${ }^{3} \mathrm{H}-\mathrm{GMP}$ into RNA for $10 \mathrm{~min}$ at $37^{\circ} \mathrm{C}$ Incubation assay and conditions are described in the Methods section Points represent means of single assays in triplicate 
placement therapy were much larger than a similar group receiving growth hormone at all ages shown ( $\mathrm{F} 1 \mathrm{~g} 2)$

Table II shows the effects of assay components and inhibitors upon the extent of incorporation of ${ }^{3} \mathrm{H}-\mathrm{GTP}$ into RNA using rat brain cortex and diencephalic cell nucle1 of normal rats No significant changes in the patterns of response to these chemical components or inhibitors were seen using nuclei derived from any of the experimental groups

Brain nuclel 1solated from groups of thyroidectomized and normal rats had identical RNA/DNA ratios of 041 (unpublished observations) Maximal in vitro synthesis of RNA (Table II) required the presence of all 4 nucleoside triphosphates, a divalent cation, DNA template, spermidine and an ATP generating system The synthesized product was acid precipitable and hydrolyzable by either RNAse or by exposure to alkalıne conditıons $\left(03 \mathrm{~N} \mathrm{KOH}, 37^{\circ} \mathrm{C}, 60 \mathrm{~min}\right)$ These characteristics are typical of this DNA-dependent RNA polymerase system ${ }^{8}$

Rates of in vitro brain RNA synthesis were a linear function of nuclear DNA concentrations for all of the nuclear preparations studied (Fig 3) RNA synthesis proceeded linearly for $10 \mathrm{~min}$, after which time no further significant synthesis occurred (Fig 4) Maximal synthesis was obtained at a $\mathrm{Mg}^{2+}$ concentration of $8 \mathrm{mM}$ (Fig 5) and at a pH close to 85 (Fig 6)

Increasing brain RNA synthesis was seen with increasing GTP concentration (constant nuclear DNA, $100 \mu \mathrm{g}$ ) up to $001 \mathrm{~m} M$ GTP (unpublished observations) Maxımal synthesis of RNA (Fig 7) was obtained at far lower nucleoside triphosphate concentrations when the incorporation system contained the ATP generating

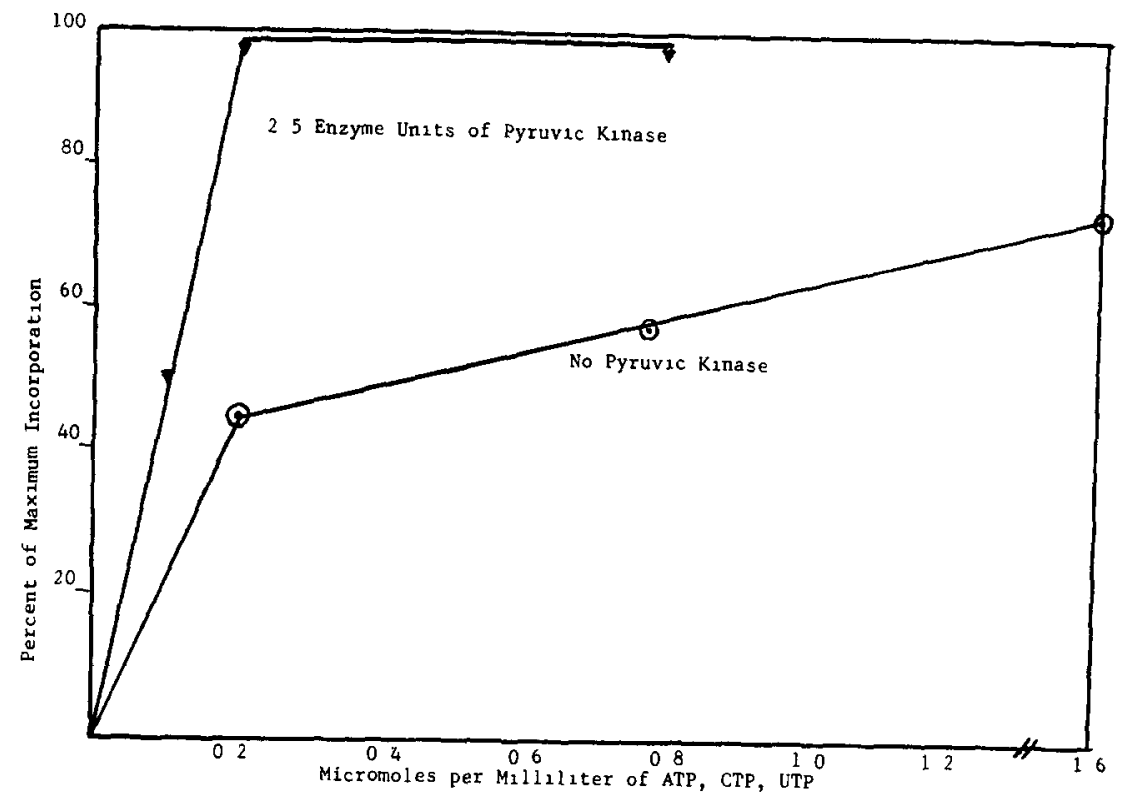

Fig 7 Effect of increasing nucleoside triphosphate concentration with constant ${ }^{3} \mathrm{H}-\mathrm{GTP}\left(03 \mu \mathrm{Cl}_{1}\right.$ and $3910^{-4} \mathrm{~m} M$ ) on incorporation into RNA in the presence and absence of an ATP generating system Normal brain nuclei $100 \mu \mathrm{g}$ of DNA were used, each point is the mean of a single assay in triplicate 
TABLE III

In utro RNA SYNTHESIS USING ISOLATED BRAIN NUCLEI OF NORMAL AND HORMONALLY ALTERED RATS

The components of the assay mixture are Tris buffer ( $\mathrm{pH} 8$ 5) $100 \mathrm{mM}$, spermidine $2 \mathrm{mM}$, 2-phosphoenol pyruvic acid $2 \mathrm{~m} M$, pyruvate kinase $25 \mathrm{E} \mathrm{U}, \mathrm{MgCl}_{2} 8 \mathrm{~m} M$, sucrose $100 \mathrm{~m} M$, ATP, CTP, UTP $02 \mathrm{mM}$ and ${ }^{3} \mathrm{H}$-GTP $002 \mathrm{mM}, 10 \mu \mathrm{C}$ Total volume $10 \mathrm{ml}$ All probability values given represent the results of a $t$-test for paired samples, data are means $\pm S E M$ Numbers in parentheses indicate number of assays Each assay was done in triplicate using two brains

\begin{tabular}{|c|c|c|c|c|}
\hline \multirow{3}{*}{$\begin{array}{l}\text { Group } \\
\begin{array}{r}\text { Female rats } \\
(22-25 \text { days old })\end{array}\end{array}$} & \multicolumn{4}{|c|}{$\begin{array}{l}\text { pMoles of GMP incorporated into RNA/mg of DNA (incubated } 10 \mathrm{~min} \text { at } \\
37^{\circ} \mathrm{C} \text { ) }\end{array}$} \\
\hline & Normal female & $\begin{array}{l}1923 \pm 134(10) \\
P<0001\end{array}$ & $\overline{\mathrm{T}}+\mathrm{T}_{4}{ }^{*}$ & $\begin{array}{l}1795 \pm 71(4) \\
P<001\end{array}$ \\
\hline & $\mathrm{T}^{*}$ female & $162 \pm 126(10)$ & $\overline{\mathrm{T}}+\mathbf{G H}^{*}$ & $1498+123(4)$ \\
\hline \multirow[t]{2}{*}{$\begin{array}{l}\text { Male rats } \\
\quad(90 \text { days old })\end{array}$} & Normal male & $\begin{array}{l}1908 \pm 13 \\
P<001\end{array}$ & & \\
\hline & $\overrightarrow{\mathrm{T}}^{*}$ male & $1622 t 102(5)$ & & \\
\hline
\end{tabular}

* Symbols defined in Methods

system These characteristics were similar in all of the brain nuclear preparations studied

The amounts of RNA synthesized per unit DNA in each nuclear preparation are presented in Table III Cerebral and diencephalıc nuclei of thyroidectomized rats (males and females) exhibited a $16 \%$ depression of in vitro RNA synthesis compared to nuclel of intact control rats $(P<0001$ and $P<001)$ respectively (Table III) Older male rather than female rats were studied to avord the possible complications resultıng from cyclic actıvity (1n female rats) of hypothalamic releasing factors and anterior pituitary hormones which might also influence the parameters studied here Nuclei from thyroidectomized rats injected $1 \mathrm{p}$ with thyroxine $(10 \mu \mathrm{g}$ of sodium L-thyroxine/100 g body weight) show greater RNA synthesis $(17 \%, P<001)$ than a paired thyroidectomized group injected with massive levels of bovine growth hormone $(100 \mu \mathrm{g} /$ day $)$ Brain RNA synthesis in the group of thyroidectomized rats receiving thyroxine was not significantly different from that seen in normal intact females but the thyroidectomized group receiving growth hormone exhibited $22 \%$ $(P<001)$ less RNA synthesis than the normal female group (Table III) Statistical comparisons between the normal female, $\overline{\mathrm{T}}+\mathrm{T}_{4}$ and the $\overline{\mathrm{T}}+\mathrm{GH}$ group were made using Student's $t$-test, these were not treated as paired samples since nucler were not simultaneously prepared and assayed

No significant changes in brain nuclear protein synthesis were observed in any of the groups shown in Table III Brain nuclei derived from all groups showed an average incorporation of 40 pmoles of leucine/mg of nuclear DNA

Liver nuclei derived from 90-day-old male rats were used to study in vitro synthesis of RNA and protein (Table IV) This liver RNA assay system was used by McGregor and Mahler ${ }^{20}$ to study RNA synthesis in liver nuclei following hormonal treatments Incorporation into hepatic RNA (Table IV) was here strictly linear for 


\section{TABLE IV}

\section{In vitro RNA AND PROTEIN SYNTHESIS IN ISOLATED RAT I IVER NUCLEI}

The components of the liver RNA assay mixture are ATP, UTP, CTP and GTP $005 \mathrm{mM}$ with $1 \mathrm{Cl}$ of ${ }^{3} \mathrm{H}$-GTP, Tris buffer (pH 85 ) $50 \mathrm{mM}, \mathrm{MgCl}_{2} 15 \mathrm{mM}$, NaF $8 \mathrm{mM}$, 2-phosphoenol pyruvate $25 \mathrm{~m} M$, pyruvate kinase $25 \mathrm{E} \mathrm{U}$ and spermidine $56 \mathrm{mM}$ Total volume $10 \mathrm{ml}$ The components of the liver nuclear protein synthesis assay mixture are $\mathrm{L}-\left[{ }^{3} \mathrm{H}\right]$ leucine $0011 \mathrm{~m} M(1 \mu \mathrm{Cl})$, sodium phosphate $(\mathrm{pH}$ 6) $100 \mathrm{~m} M$, 2-phosphoenol pyruvate $2 \mathrm{mM}$, pyruvate kınase $25 \mathrm{E} \mathrm{U}, \mathrm{MgCl}_{2} 2 \mathrm{mM}$ and sucrose $100 \mathrm{~m} M$ Probability values represent the results of a $t$-test for paired samples Values are means \pm $S E M$ Numbers in parentheses indicate number of assays, each in triplicate

\begin{tabular}{lll}
\hline Group* & $\begin{array}{l}R N A \text { synthesis (pmoles of GMP into } \\
\text { RNA in } 5 \text { min } 37^{\circ} \mathrm{C} \text {, per mg of DNA) }\end{array}$ & $\begin{array}{l}\text { Protem synthesis (pmoles of leucine into } \\
\text { protein in } 20 \text { min } 37^{\circ} \mathrm{C} \text {, per mg of DNA) }\end{array}$ \\
\hline Normal & $2528 \pm 335(4)$ & $193 \pm 46(7)$ \\
$\overline{\mathrm{T}}$ & $P<001$ & not significantly different \\
& $1423 \pm 393(4)$ & $252 \pm 38(7)$
\end{tabular}

* 90-day-old male rats were used, symbols defined in Methods section

5 min (data not shown) for both normal and thyroidectomızed rat liver nucle Nucle1 1solated from livers of hypothyroid rats showed $43 \%$ less RNA synthesis per unit DNA $(P<001)$ than normal control rat liver nucle1, again no significant detectable changes in hepatic nuclear protein synthesis were observed

\section{DISCUSSION}

These studies demonstrate depressed levels of brain and liver RNA synthesis subsequent to neonatal radiothyroidectomy Chronic administration of physiological levels of thyroxine restored brain RNA synthesis to normal while simılar admınistration of massive levels of growth hormone was ineffective, suggesting a degree of hormonal specificity of responsiveness Krawiec et al ${ }^{19}$, in contrast, found growth hormone at least as effective as triodothyronıne in restoring the brain weight, the DNA and RNA of neonatally thyrordectomized rats to normal levels Geel and Timiras $^{13}$, however, reported growth hormone ineffective in the latter regards Nuclear protein synthesis (both brain and liver) appeared unaffected by thyroidectomy as studied here Since only total nuclear RNA and total acid-precipitable nuclear protein were studied, rather than specific classes of RNA and nuclear protein, it may be that changes in specific classes of RNA or nuclear protein went undetected because the altered component represented a very small portion of the total in vitro synthesis

These reductions of in vitro synthesis of brain or liver RNA could conceivably be the result of an altered permeability to RNA precursors at the nuclear membrane or at intranuclear synthetic sites This is deemed unlikely since nuclei from both normal and hormonally altered rat brain showed no significant differences in the extent of stimulation of RNA synthesis when all 4 nucleoside triphosphates were added to the incomplete assay system containing one of the four (GTP) These results can also be caused by an enhanced nuclease content or the presence of inhibitory factors in the hypothyrold rat brain nuclear fraction However, mixing experiments (unpublished 
studies) did not suggest this to be the case since mixing normal brain nuclei and nucle from thyroidectomized rats always resuited in an incorporation which was equal to the sum of each, when studied separately This was true even when the intact nucle were totally disrupted allowing for the mixing of possible nuclease or inhibitory factors Alterations of template efficiency or a reduced activity of the RNA polymerase enzyme do appear likely explanations Although exact mechanısms remain undefined the developmental responses mediated by thyroxine in both rat brain and liver do involve the synthesis of RNA Gispen et al ${ }^{15}$ showed depressed levels of all classes of RNA in rat brain stem following hypophysectomy Hormones may then act as metabolic regulators in brain as in peripheral organs by changing RNA synthesis These hormonal controls would appear to apply to postulates discussed by McIllwain $^{21}$ suggesting brain metabolic adaptation in response to inducing agents requiring a changed synthesis of RNA These results also suggest that thyroid hormone fulfills a role in developing mammalian brain as a differentıatıng agent and which does have an influence on RNA synthesis This influence upon RNA synthesis may in turn serve a regulatory role in brain protein synthesis and the development of a mature pattern of brain enzyme synthesis

SUMMARY

Depression of rat brain and liver RNA synthesis was seen at 22 and 90 days subsequent to neonatal radiothyroidectomy Cerebral RNA synthesis (per unit DNA) was depressed by $16 \%(P<0001)$ while hepatic RNA synthesis was reduced by $43 \%(P<001)$ Nuclear protein synthesis was not detectably altered RNA and protein synthesis determinations were conducted, using isolated nuclei in standardized in vitro assay systems which circumvented complications (often seen in vivo approaches) such as pool size changes, cell membrane transport alterations and mediation of blood-brain barrier related effects

Chronic dally administration in vivo of L-thyroxine $(10 \mu \mathrm{g} / 100 \mathrm{~g}$ body weight) restored the depressed cerebral synthesis of RNA to normal levels while daily administration of bovine growth hormone (100 $\mu \mathrm{g}$ per rat) did not

\section{ACKNOWLEDGEMENTS}

The author is grateful to Dr Lawson L Rosenberg for actıng as thesis advisor and for donations of $131 \mathrm{I}$ and growth hormone during this study

Supported by NIH pre-doctoral fellowship, No 5-F01-GM-35, 989-03 and carried out at the University of Calıfornia, Berkeley, Department of PhysiologyAnatomy

\section{REFERENCES}

1 ARdolovic, N, AND Kochakian, C D , Androgen regulation of RNA polymerase activity in isolated mouse kıdney nucleı, Bıochım biophys Acta (Amst), 182 (1969) 382-393 
2 BaLÁzs, R, AND GaITONDE, M K , Factors affectıng protein metabolism in the brain, Blochem $J$, $106(1968) \mathrm{lp}$

3 Balázs, R , Kovacs, S, Teichgraber, P , Cocks, W A, and Eayrs, J T , Biochemical effects of thyroid deficiency on the developing rat brain, $J$ Neurochem, 15 (1968) 1335-1349

4 Bucher, N L R, AND Swaffield, M N, Ribonucleic acid synthesis in relation to precursor pools in regeneratıng rat liver, Bıochim Biophys Acta (Amst), 174 (1969) 491-502

5 Burton, $K$, A study of the conditions and mechanısm of the diphenylamine reaction for the colorimetric estımation of deoxyrıbonucleic acid, Bıochem $J, 62$ (1955) 315-322

6 Caviezel, F, and Martini, L, Hormones and brain development In R Paoletti and A $\mathbf{N}$ Davison (Eds), Chemistry and Brain Development, Advances in Experimental Medicine and Biology, Vol 13, Plenum Press, New York, 1971, p 215

7 Dainat, J, Rebiere, A, et Le Grand, J, Influence de la déficience thyroıdienne sur l'incorporatıon in vivo de la L- $\left[{ }^{3} \mathrm{H}\right]$-leucıne dans les protéınes du cervelet chez le jeune rat, $J$ Neurochem, 17 (1970) 581-586

8 Dutton, G R, AND MAHLER, H R, In vitro synthesis of RNA by intact rat brain nuclei, $J$ Neurochem , 15 (1968) 765-780

9 EAYrs, J T, The vascularity of the cerebral cortex in normal and cretinous rats, $J$ Anat (Lond), 88 (1954) 164

10 Garcia Argiz, C A, Pasquini, J M, Kaplun, B , and Gomez, C J , Hormonal regulation of brain development, Brain Research, 6 (1967) 635-646

11 Geel, S E, AND Timiras, P S, Influence of neonatal hypothyroidism and of thyroxine on the acetylcholinesterase and cholinesterase activities in the developing central nervous system of the rat, Endocrinology, 80 (1967) 1069-1074

12 GeEl, S E, AND TimiRAS, P S, Effect of neonatal hypothyroidism and of thyroxine on $\mathrm{L}_{-}\left[{ }^{14} \mathrm{C}\right]-$ leucine incorporation in protein in vivo and the relationship to ionic levels in the developing brain of the rat, Brain Research, 4(1967) 143-150

13 GeEL, S E, AND Timiras, P S , Influence of growth hormone on cerebral cortical RNA metabolism in immature hypothyrold rats, Brain Research, 22 (1970) 63-72

14 GeEL, S E , AND TimiRAS, P S , The role of hormones in cerebral protein metabolism In A LAJTHA (Ed ), Protein Metaboltsm of the Nervous System, Plenum Press, New York, 1970, p 335

15 Gispen, W H , De Wied, D , Schotman P , AND JANSz, H S , Effects of hypophysectomy on RNA metabolism in rat brain stem, $J$ Neurochem , 17 (1970) 751-761

16 GoldberG, R C, AND Chaikoff, I L , A simplified procedure for thyroidectomy of the newborn rat without concomitant parathyro1dectomy, Endocrinology, 45 (1949) 64-70

17 Hamburgh, M H, and FleXNer, L B, Biochemical and physiological differentiation during morphogenesis XXI, J Neurochem, 1 (1957) 279-288

18 Kochakian, D C , AND HiLl, J , Effect of androgen on the incorporation of orotic acid $6-14 \mathrm{C}$ into the ribonucleic acids and free nucleotides of mouse kidney, Btochemistry, 5 (1966) 1696-1701

19 Krawiec, L , Garcia Argiz, C A , Gomez, C J , and Pasquini, J M, Hormonal regulation of brain development III Effects of trilodothyronine and growth hormone on the biochemical changes in the rat, Brain Research, 15 (1969) 209-218

20 MACGregor, R R , AND MAHLER, H R, RNA synthesis in intact rat liver nuclei, Arch Biochem Blophys , 120 (1967) 136-157

21 McIllwain, H, Metabolic adaptation in the brain, Nature (Lond), 226 (1970) 803-806

22 Munro, H N, Determination of nucleic acids In D Glick (Ed), Methods of Blochemical Analysts, Vol 14, Wiley, New York, 1966, p 113

23 MYANT, N B , The role of the endocrine glands in mammalian brain development In R PAOLETTI AND A N Davison (Eds), Chemistry and Brain Development, Advances In Experimental Medicine and Biology, Vol 13, Plenum Press, New York, 1971, p 227

24 PAPKOFF, $\mathbf{H}$, AND $\mathrm{LI}, \mathrm{C} \mathbf{H}$, The isolation and characterization of growth hormone from anterior lobes of whale pituitaries, $J$ biol Chem , 231 (1958) 367-377

25 Ramirez de Guglielmone, A. E , Duvilanski de Feldguer, B , e Gomez, C J , Sintesis de RNA en cerebro de ratas normales e hipotıroldeas, Congr Arg Cienc Biol, Buenos Atres, (1970) 118

26 Rappoport, D A, Maxcy, P, and Daginawala, Nuclei In A Lajtha (Ed), Handbook of Neurochemistrv, Vol 2, Plenum Press, New York, 1969, p 241

27 Sporn, M B , Wanko, T, AND Dingman, W, The isolation of cell nuclei from rat brain, $J$ Cell Biol, 15 (1962) 109-120

28 Szijan, I, Kalbermann, L E, and Gomez, C J , Hormonal regulation of brain development IV. 
Effect of neonatal thyroidectomy upon incorporation in vivo of $\mathrm{L}-\left[{ }^{3} \mathrm{H}\right]$ phenylalanıne into proteins of developing rat cerebral tissues and pituitary gland, Brain Research, 27 (1971) 309-318

29 TATA, J R , AND Widnell, C C , Ribonucleic acid synthesis during the early action of thyroid hormones, Blochem $J, 98$ (1966) 604-620

30 Valcana, T, and Timiras, P S, Effect of hypothyroidism on ionic metabolism and Na-K activated ATP phosphohydrolase activity in the developing rat brain, $J$ Neurochem, 16 (1969) 935-943 